\title{
Growth and survival of Indian salmon Eleutheronema tetradactylum (Shaw, 1804) in Brackish water pond.
}

\begin{abstract}
This study was conducted to assess the growth performance and survival rate of a commercially important finfish Eleutheronema tetradactylum in $100 \mathrm{~m}-2$ of sandy clay brackish water earthen ponds. Wild $36.14 \mathrm{~g}$ of E. tetradactylum juveniles were stocked at 0.5 individuals m-2 and cultured for 45 days by feeding trash Muraenesox sp. (pike eel) at $12 \mathrm{~h}$ intervals. Average body weight of E. tetradactylum was found $75 \pm 5.6 \mathrm{~g}$ for treatment ponds and $65 \pm 3.57 \mathrm{~g}$ for control ponds at the end of experiment. Feed Conversion Ratio (FCR) was 2.3 with the survival rate of $70-80 \%$ at the end of the culture in the experimental culture ponds. The results of the present study suggest that the production of four finger thread fin could still be increased up to the marketable size if it is done for 5-6 months culture period by feeding trash fish.
\end{abstract}

Keyword: Aquaculture; Coastal belt; Earthen pond; Eleutheronema tetradactylum; Four finger thread finfish. 